with occasional peaks up to 17 . Furthermore, the peak in charcoal abundance inferred by Verardo and Ruddiman ${ }^{17}$ at the Last Glacial Maximum corresponds to samples with a very small range of $\mathrm{C} / \mathrm{N}$ ratios between 8 and 12, suggesting that these samples are predominantly composed of marine-derived carbon. Isolated peaks in $\mathrm{C} / \mathrm{N}$ ratio up to 18 in some samples may correspond to events similar to those identified in ODP-668B.

Second, the flux rates of elemental carbon calculated by Verardo and Ruddiman ${ }^{17}$ range as high as $50,000 \mu \mathrm{g} \mathrm{cm}^{-1} \mathrm{kyr}^{-1}$, which is two orders of magnitude higher than calculated for a range of recent, Quaternary and Tertiary marine sediments by other researchers. Smith et al. ${ }^{16}$ calculated an average pre-industrial flux rate for Pacific and Atlantic sediments of $100 \mu \mathrm{g} \mathrm{cm}^{-1} \mathrm{kyr}^{-1}$, whereas Herring ${ }^{11}$ calculated Quaternary fluxes of $3-600 \mu \mathrm{g} \mathrm{cm}^{-1} \mathrm{kyr}^{-1}$ and Tertiary fluxes of $0.3-10 \mu \mathrm{g} \mathrm{cm}^{-1} \mathrm{kyr}^{-1}$ for Pacific Ocean sediments remote from coastal regions. These values agree well with the OREC fluxes calculated for ODP-668B $\left(1-400 \mu \mathrm{g} \mathrm{cm}^{-1} \mathrm{kyr}^{-1}\right)$, despite the fact that the data were generated by different techniques.

A sample of Antarctic marine sediment previously shown by Bird and Gröcke ${ }^{28}$ to contain $<1 \%$ elemental carbon was analysed in triplicate using the Verardo and Ruddiman ${ }^{17}$ technique. The results indicate that only $49 \pm 5 \%$ of the carbon in this sample was removed by in situ nitric acid oxidation, implying an elemental carbon content of around $50 \%$. It is possible that, whereas some organic carbon is oxidized directly to $\mathrm{CO}_{2}$, a considerable quantity of more refractory organic carbon is only partly oxidized and solubilized by the treatment but not removed, leading to an overestimate of 'charcoal' abundance using the Verardo and Ruddiman technique.

The OREC results from our study suggest that during the transition from interglacial to glacial mode the regional climate may have been destabilized and highly variable, leading to the buildup of fuel loads during wet periods followed by intense biomass burning in subsequent dry periods. In addition, biomass burning may be one mechanism by which high terrestrial organic carbon stocks built up during interglacials are shed at the onset of the subsequent glaciation.

The most recent peak in OREC abundance is unique in the past million years, in that it has occurred during an interglacial period. Anthropogenic biomass burning is considered the likely cause of this peak. Given that the current conditions of interglacial aridity in the region are also considered by some to be unusual ${ }^{5-7,22}$, further consideration should be given to the possibility that a range of human activities in sub-Saharan Africa may have resulted in regional modifications to 'natural' vegetation patterns and climate.

Received 22 July 1997; accepted 9 June 1998

1. Xue, Y. The influence and mechanisms of biosphere feedback on African climate. Int. Ass. Hydrol. Sci. Publ. 214, 119-125 (1993).

2. Hao, W. M., Liu, M.-H. \& Crutzen, P. J. in Fire in the Tropical Biota (ed. Goldammer, J. G.) 452-465 (Ecological Studies Monogr. 184, Springer, Berlin, 1990).

3. Andreae, M. O. in Global Biomass Burning: Atmospheric, Climatic and Biospheric Implications (ed. Levine, J. S.) 1-23 (MIT Press, Cambridge, MA, 1991).

4. Bird, M. Fire, prehistoric humanity and the environment. Interdisc. Sci. Rev. 20, 131-154 (1995).

5. Kammen, D. M. \& Marino, B. D. On the origin and magnitude of pre-industrial anthropogenic $\mathrm{CO}_{2}$ and $\mathrm{CH}_{4}$ emissions. Chemosphere 26, 69-77 (1993).

6. Schulz, E. Human impact and the anthropogenic nature of the west African Sahel. Progr. Abstr. InterINQUA (Canberra, Australia) 73 (Spec. Publ. Austral. Quat. Ass., Canberra, 1993).

Hulme, M. \& Kelly, M. Exploring the links between desertification and climate change. Environment 35, 5-45 (1993).

8. Petit-Maire, N. Lire l'avenir dans les archives Géologiques. Recherche 23, 556-564 (1992).

9. Rowell, D. P. et al. Modelling the influence of global sea surface temperatures on the variability and predictability of seasonal Sahel rainfall. Geophys. Res. Lett. 9, 905-908 (1992).

10. Smith, D. M., Griffin, J. J. \& Goldberg, E. D. Spectrometric method for the quantitative determination of elemental carbon. Anal. Chem. 47, 233-238 (1975).

11. Herring, J. R. in The Carbon Cycle and Atmospheric $\mathrm{CO}_{2}:$ Natural Variations from Archean to Present 419-442 (Geophys. Monogr. 32, Am. Geophys. Un., Washington DC, 1985).

12. Wolbach, W. S. \& Anders, E. Elemental carbon in sediments: Determination and isotopic analysis in the presence of kerogen. Geochim. Cosmochim. Acta 53, 1637-1647 (1989).

13. Emiliani, C., Price, D. A. \& Seipp, J. in Stable-Isotope Geochemistry: A tribute to Samuel Epstein (eds Taylor, H. P., O’Neil, J. R. \& Kaplan, I. R.) 229-231 (Spec. Publ. No. 3, Geochemical Soc., San Antonio, 1991)

14. Verardo, D. J. Charcoal analysis in marine sediments. Limnol. Oceanogr. 42, 192-196 (1997)

15. Wolbach, W. S. et al. Global fire at the Cretaceous-Tertiary boundary. Nature 334, 665-669 (1988)

16. Smith, D. M., Griffin, J. J. \& Goldberg, E. D. Elemental carbon in marine sediments: a baseline for burning. Nature 241, 268-270 (1973).
17. Verardo, D. J. \& Ruddiman, W. F. Late Pleistocene charcoal in tropical Atlantic deep-sea sediments: climatic and geochemical significance. Geology 24, 855-857 (1996).

18. Cachier, H., Bremond, M. P. \& Buat-Menard, P. Carbonaceous aerosols from different tropical biomass burning sources. Nature 340, 371-373 (1989).

19. Smith, B. N. \& Epstein, S. Two categories of ${ }^{13} \mathrm{C} /{ }^{12} \mathrm{C}$ ratios for plants. Plant Physiol. 47, 380-384 (1971).

20. Ruddiman, W. F. et al. Site 668. Proc. Init. Rep. ODP Leg 108 (pt 2), 931-951 (1988).

21. Parkin, D. W., Phillips, D. R. \& Sullivan, R. A. L. Airborne dust collection over the North Atlantic. J. Geophys. Res. 75, 1782-1793 (1970).

22. Pokras, E. M. \& Mix, A. C. Eolian evidence for spatial variability of Late Quaternary climates in tropical Africa. Quat. Res. 24, 137-149 (1985).

23. deMenocal, P. B. Plio-Pleistocene African climate. Science 270, 53-59 (1995).

24. Dupont, L. Vegetation zones in NW Africa during the Bruhnes Chron reconstructed from marine palynological data. Quat. Sci. Rev. 12, 189-202 (1993).

25. Sarnthein, M. et al. Stable-isotope stratigraphy for the last 750,000 years: "Meteor" core 13519 from the eastern equatorial Atlantic. Meteor Forsch. C 38, 9-24 (1984).

26. Müller, P. J., Erlenkeuser, H. \& von Grafenstein, R. in Coastal Upwelling: its Sedimentary Record (eds Theide, J. \& Suess, E.) 365-398 (Plenum, New York, 1981).

27. Verardo, D. J. \& McIntyre, A. Production and destruction: control of biogenous sedimentation in the tropical Atlantic 0-300,000 years B.P. Paleoceanography 9, 63-86 (1994).

28. Bird, M. I. \& Gröcke, D. Determination of the abundance and carbon-isotope composition of elemental carbon in sediments. Geochim. Cosmochim. Acta 61, 3413-3423 (1997).

Acknowledgements. We thank P. Weiss and C. Mato for assistance with the provision of samples from ODP-668B. This work was supported by a Queen Elizabeth II fellowship to M.I.B. from the Australian Research Council.

Correspondence and requests for materials should be addressed to M.I.B. (e-mail: michael.bird@anu. edu.au)

\section{Diachronous uplift of the Tibetan plateau starting 40 Myr ago}

\section{Sun-Lin Chung*, Ching-Hua Lo*, Tung-Yi Lee $\dagger$, Yuquan Zhang $\ddagger$, Yingwen Xie $\ddagger$, Xianhua Li $¥$, Kuo-Lung Wang* \& Pei-Ling Wang*}

${ }^{*}$ Department of Geology, National Taiwan University, Taipei, Taiwan $\dagger$ Department of Earth Sciences, National Taiwan Normal University, Taipei, Taiwan

$\ddagger$ Guangzhou Institute of Geochemistry, Chinese Academy of Sciences, Guangzhou, Guangdong

The uplift of the Tibetan plateau is generally regarded as a response to the convective removal of the lower portion of the thickened Asian lithosphere ${ }^{1}$. This removal is also thought to be responsible for the east-west extension ${ }^{2}$ that took place during the India-Asia collision. The timing of these events has been a subject of great interest for understanding mountain-building processes, collisional tectonics and the influence of these processes on climate change ${ }^{3,4}$. In western Tibet, potassic lavas related to east-west extension were found to have been extruded over the past $20 \mathrm{Myr}$ (refs 5, 6). Here we report the widespread occurrence of magmas in eastern Tibet which show similar geochemical signatures to the potassic lavas to the west but formed 40$30 \mathrm{Myr}$ ago. These magmatic activities suggest a diachronous uplift history for the Tibetan plateau, with the convective removal of the lower lithosphere inducing rapid uplift in the east beginning some $40 \mathrm{Myr}$ ago and in the west about $20 \mathrm{Myr}$ later. This observation is consistent with sedimentation records from the Ganges-Brahmaputra delta to the Bengal $\mathrm{fan}^{7,8}$ and can better account for the tectonically driven models for strontium isotope evolution in the ocean ${ }^{9}$ and global cooling ${ }^{10}$ over the past 40 Myr.

The collision of India with Asia since early Cenozoic time has created the Tibetan plateau. The widespread occurrence of northsouth-striking normal faults in Tibet (Fig. 1), starting before $14 \mathrm{Myr}$ $\mathrm{ago}^{2}$, suggests a switch of the tectonic regime from north-south convergence to east-west extension that could have resulted from convective removal of the lower part of lithospheric mantle by hotter and lighter asthenosphere ${ }^{1}$. The latter process may furthermore have caused a sudden increase in the surface elevation and 
perturbation of the geotherm, and thus induced potassic melt generation via small-degree melting of remnant lithospheric mantle if it had been previously enriched. Geochronological studies of movement of the normal faults ${ }^{2}$, emplacement of the potassic magmas $^{5,6}$, and unroofing of basement rocks ${ }^{3,11}$, have provided important constraints on the geodynamic evolution of the plateau. A widely accepted interpretation is that the rapid uplift of Tibet began around 20-13 Myr ago (refs 2-6). It is, however, based exclusively on information from the western part of the Tibetan plateau, that is, from regions located west of Lhasa or west of about $92^{\circ} \mathrm{E}$ (Fig. 1).

Compared with the investigations of western Tibet that form the present basis for understanding the Tibetan evolution, one of the few results from eastern Tibet is the discovery of late Palaeogene alkaline magmatic rocks ${ }^{12}$. The rocks, divided here into five groups, are exposed around three tectonic belts, namely, the northern Ailao Shan-Red River shear zone, the Batang-Litang fault system and the Jinsha suture (Fig. 1). These magmas, however, were poorly known and their geodynamic significance remains unrecognized. A trachyte plug from the westernmost part of the magma suite (that is, from group 5) was the only outcrop documented in international publications $^{13}$. The alkaline rocks, emplaced $\sim 30 \mathrm{Myr}_{\text {ago }}{ }^{12,14}$, occur as small extrusive and intrusive bodies and consist of mafic to felsic lithologies. To the south, in eastern parts of the Lhasa block and the
Himalayas, contemporaneous igneous rocks (group 6) with similar petrological and geochemical characteristics have been reported in several localities ${ }^{15}$. Their easternmost counterpart crops out in the China-Vietnam border, where late Palaeogene potassic rocks have been transported from the eastern margin of Tibet by the midTertiary sinistral movement along the Ailao Shan-Red River shear zone $^{16}$. Therefore, the late Palaeogene alkaline rocks are considered widespread in the entire region of eastern Tibet.

Here we present $\mathrm{Ar}-\mathrm{Ar}$ and $\mathrm{K}-\mathrm{Ar}$ dating results of a variety of the alkaline rocks from groups $1-5$ in eastern Tibet, and define a magmatic duration of 40-30 Myr ago (Table 1 and Fig. 2). Geochemically, these rocks range from basaltic to trachytic and rhyolitic composition (Fig. 3a). They show ultra-potassic or shoshonitic character that is comparable to Neogene ( $<20 \mathrm{Myr}$ old $)$ potassic volcanics ${ }^{5,6}$ emplaced in the western part of the Tibetan plateau (Fig. 3b). The similarity can also be shown by trace-element systematics of mafic rocks from the two magma suites of different ages. They both have incompatible trace-element variation patterns, with highly enriched large-ion lithophile elements $(\mathrm{Rb}, \mathrm{Ba}$, Th and $\mathrm{U})$, light rare-earth elements and lead, and depleted high-fieldstrength elements, that is, $\mathrm{Nb}, \mathrm{Ta}, \mathrm{Zr}$, Hf and Ti (Fig. 3c). Such potassic magmas, particularly those with high $\mathrm{MgO}$ contents $(>10 \mathrm{wt} \%)$, require a metasomatized, phlogopite-bearing peridotite source residing in the lithospheric mantle (see ref. 6 for details).

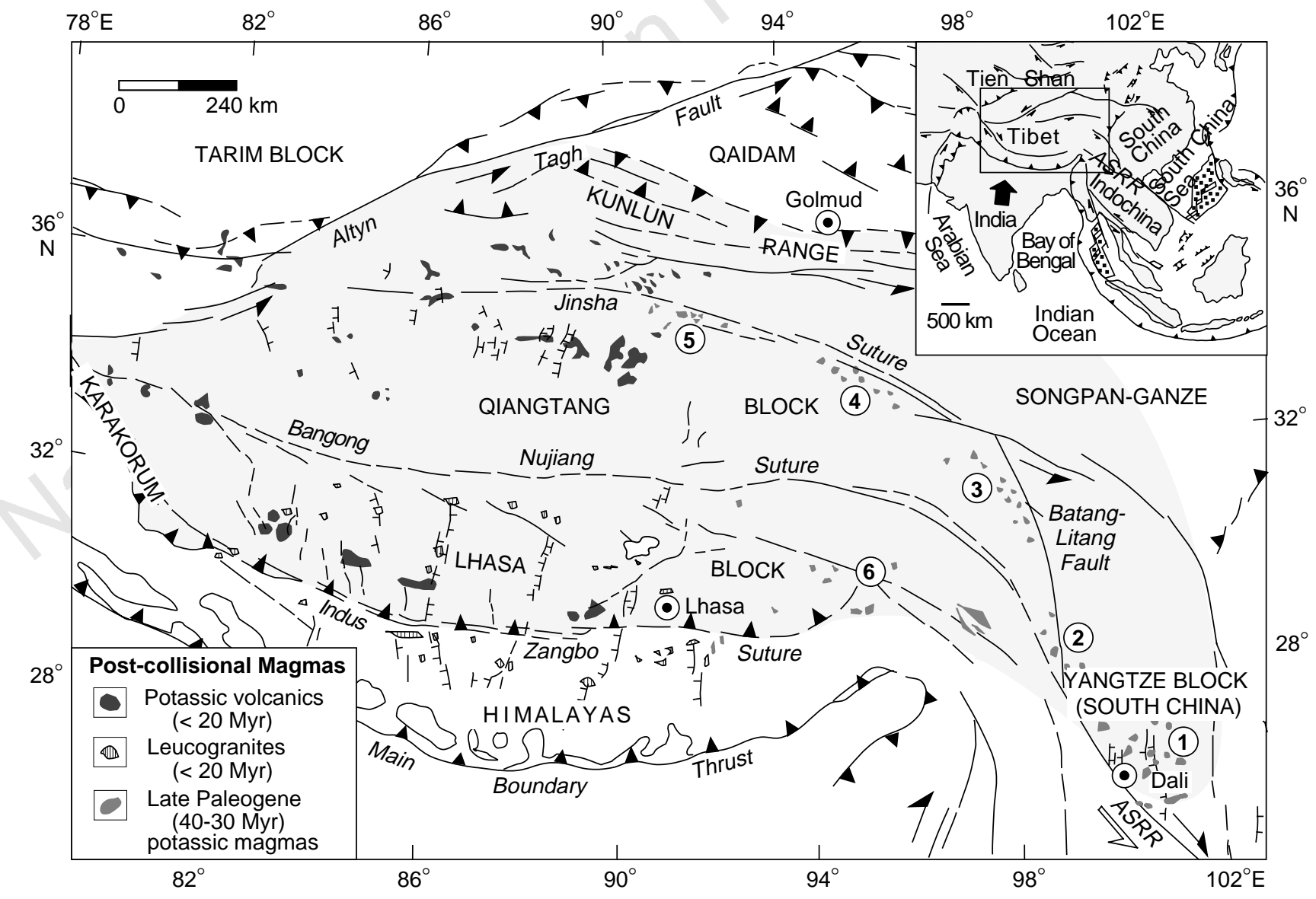

Figure 1 Simplified tectonic map of area around the Tibetan plateau (shaded area). Shown are the main tectonic blocks, structures, north-south-trending normal faults (after ref. 2), and post-collisional magmatic rocks (after refs 6, 12, 16 and 34). Inset shows tectonic units of southeast Asia related to the India-Asia collision (after ref. 28). The late Palaeogene, 40-30 Myr old, potassic magmas emplaced in eastern Tibet, east of $92^{\circ} \mathrm{E}$, are classified into six groups. In this study, 100 potassic rocks were collected from groups 1-5, and 40 samples were dated (see Table 1 and Fig. 2). We note that the restricted sampling is due to the locations of river valleys and road cuts along the Jinsha River area, which were the only places accessible in this mountainous region. Although samples from group 6 were unavailable, their easternmost counterpart has been identified in the Vietnam-China border ${ }^{16}$ because of the $600-\mathrm{km}$ sinistral block movement along the Ailao Shan-Red River (ASRR) shear zone. Samples from the latter have similar lithologies and chemical compositions and are synchronous with those from groups 1-5, so are considered co-genetic. 
Changes in the tectonic setting are often recorded by changes in composition of the magmas formed. Eruption of the widespread, though small-volume, Neogene potassic larvas in western Tibet (Fig. 1) has been proposed to constrain the timing of the Tibetan uplift and lithospheric thinning in the region ${ }^{5,6}$. The geothermal structure required to trigger melting in the lithospheric mantle could have been obtained only if the lower part of thickened Asian lithosphere was convectively removed and replaced by the asthenosphere ${ }^{1,5,6}$. In eastern Tibet, the late Palaeogene potassic rocks from groups $1-5$ are seemingly confined to three tectonic belts. However, the Jinsha suture represents an early Mesozoic suture and was inactive in the Cenozoic ${ }^{15,17}$, and both the Ailao Shan-Red River and Batang-Litang fault systems display prominent strike-slip components active in the late Cenozoic ${ }^{16-18}$. Motions of these tectonic belts could not have been responsible for generation

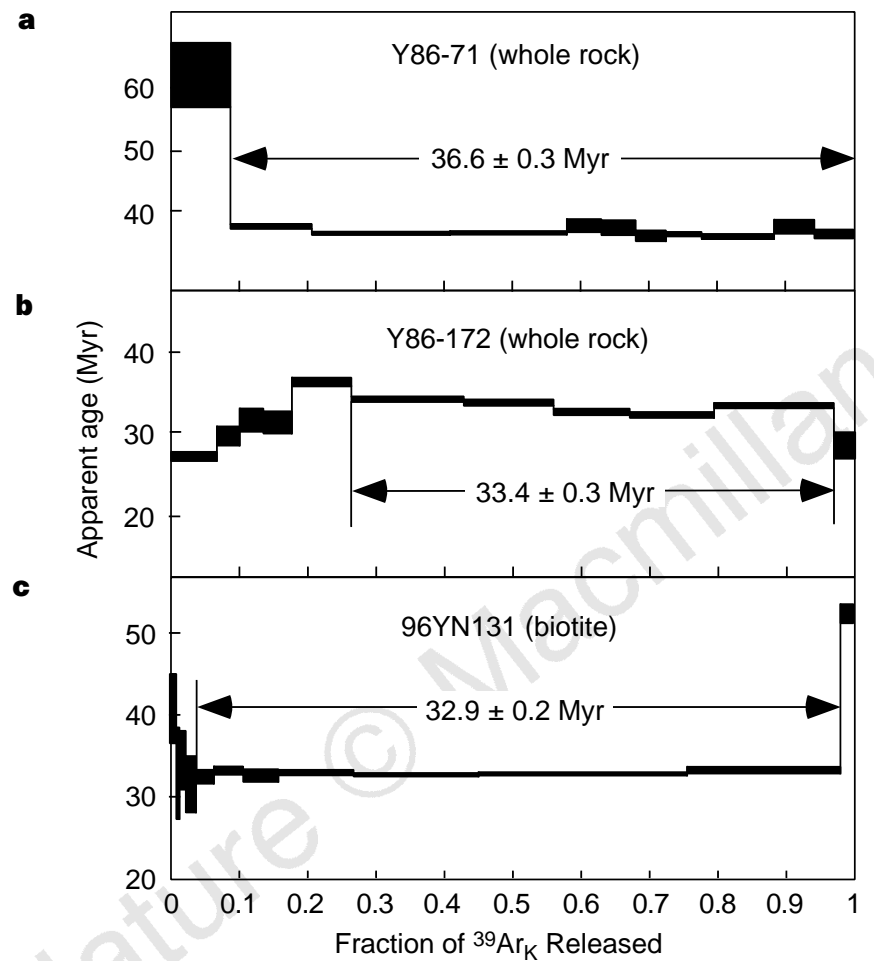

d

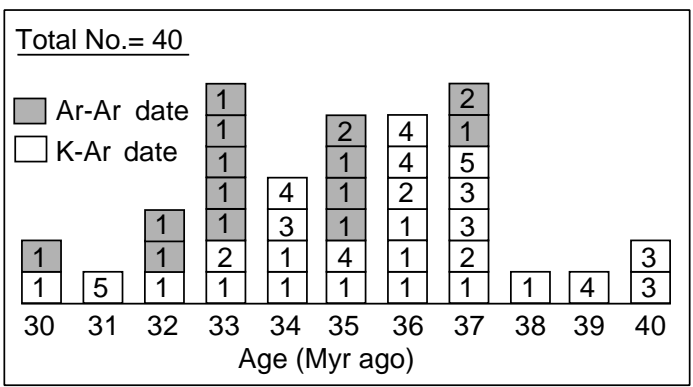

Figure 2 Representative ${ }^{40} \mathrm{Ar}-{ }^{39} \mathrm{Ar}$ radiometric dating spectra. Shown are data for two whole rocks, Y86-71 (a) and Y86-172 (b), and a biotite separate, 96YN-13 (c), of potassic rocks from eastern Tibet. Plateau dates are shown with one standard error between arrows to indicate gas fractions included in age calculations. In d, a histogram of a total of 40 dates obtained by K-Ar and Ar-Ar methods is shown, thus defining a magmatic duration of 40-30 Myr ago. In addition to $26 \mathrm{~K}$-Ar results covering five groups of sample locations (shown with numbers), the Ar-Ar age determinations were done for eight whole rocks and six mineral separates from groups 1 and 2. Detailed $\mathrm{Ar}$-Ar age data and their experimental conditions, and major-element compositions of the samples dated, are available; see Supplementary Information.

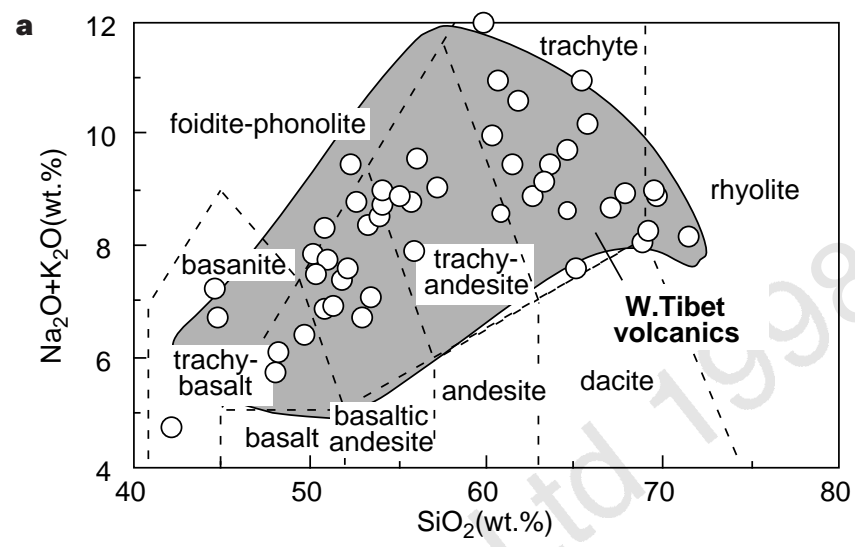

b
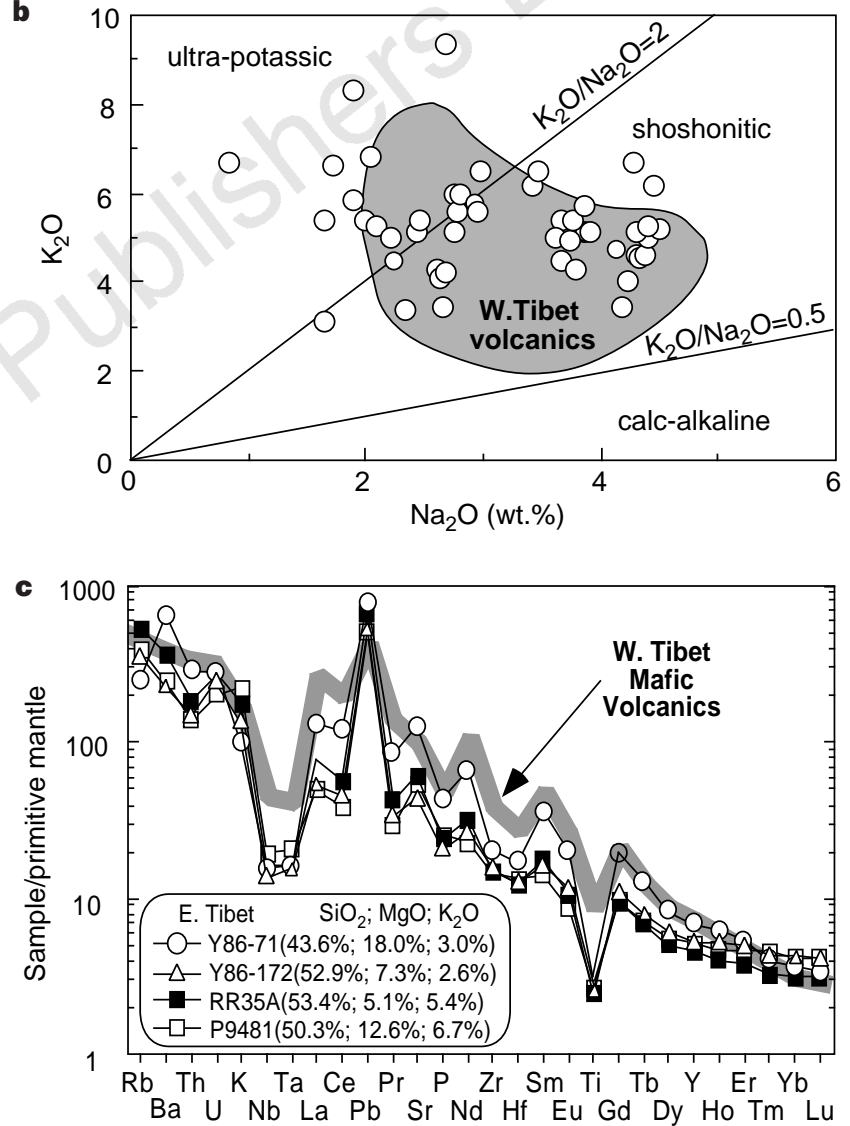

Figure $\mathbf{3}$ Comparison of compositions of rocks from eastern and western Tibet. Late Palaeogene magmatic rocks from eastern Tibet are plotted on $\mathbf{a}$, total alkalis versus silica, b, potassium versus sodium, and $\mathbf{c}$, primitive-mantle-normalized incompatible element variation diagrams, showing geochemical similarities with the Neogene potassic lavas from western Tibet. Data for the latter are from ref. 6. Classification schemes in $\mathbf{a}$ and $\mathbf{b}$ are according to ref. 35 , and the normalizing values in $\mathbf{c}$ are from ref. 36 . Major- and trace-element data plotted were obtained by $\mathrm{X}$-ray fluorescence and dissolution inductively coupled plasma mass spectrometry methods at National Taiwan University and the Chinese Academy of Sciences, respectively, with the analytical uncertainties generally better than $5 \%$. Likewise, both the potassic magma suites from Tibet have significantly lower neodymium and higher strontium isotopic ratios than those of the depleted convecting mantle. Combined elemental and isotopic data indicate that an enriched peridotite source containing phlogopite, which resides possibly within the lithospheric mantle, is required. The enrichment may have been related to certain ancient events or substantial amounts of sediment contamination by the Mesozoic Tethyan subduction zone processes (Y.Z., S.L.C., Y.X. and X.L., manuscript in preparation). 
of the late Palaeogene, lithospheric-mantle-derived potassic melts. Thus, the occurrence of the two potassic magma suites suggests a diachronous lithospheric thinning beneath the Tibetan region. By analogy with formation of the younger suite associated with geothermal perturbation, normal faulting ${ }^{2}$ and rapid increase in the elevation ${ }^{3,11}$ in western Tibet starting $20 \mathrm{Myr}$ ago, the plateau may have undergone similar tectonomagmatic processes in its eastern part since as early as $40 \mathrm{Myr}$ ago.

In comparison with the widely cited age of 50-45 Myr for the onset of the India-Asia collision, Beck et al. ${ }^{19}$ reported stratigraphic evidence for an earlier collision in northwest India before $\sim 56 \mathrm{Myr}$ ago. According to changes of the convergence rate derived from the northward motion of the Indian Ocean plate ${ }^{20}$, a collision of India with Asia at the east end might have occurred since $\sim 60 \mathrm{Myr}$ ago. In this sense, the lithosphere underneath eastern Tibet could have reached its maximum sustainable thickness and thus being removed $\sim 40 \mathrm{Myr}$ ago. This could have caused a sudden uplift, regional extension and the potassic magmatism in eastern Tibet. Such processes could have reached as far as western Yunnan in the South China block, as shown by the abundance of late Eocene to Oligocene rifted basins east of Diancangshan ${ }^{21,22}$, northwest of Dali (Fig. 1), where potassic magmas of group 1 occur. Thus, western Yunnan at the eastern margin of Tibet consists of thinner crust $(\sim 40-45 \mathrm{~km}$; ref. 23$)$ and lower relief $\left(\sim 2 \mathrm{~km}\right.$ on average $\left.\mathrm{e}^{21}\right)$ relative to the rest of the plateau. It may be a consequence of "extensional collapse", a process occurring after convective lithospheric thinning that in many cases has changed continental collision zones from mountains to basins ${ }^{24}$.

Voluminous sediments related to the India-Asia collision have been accumulated in the Bengal fan (see ref. 8 for a review). Although the High Himalaya is generally regarded as an important source for sediments in the Bengal $\mathrm{fan}^{8,25}$, a volume balance calculation $^{26}$ showed that the Himalayas cannot be the only sediment source and its hinterland (the Tibetan plateau) must have been significantly involved in shedding sediments before $20 \mathrm{Myr}$ ago. Additionally, an onshore seismic stratigraphic analysis ${ }^{7}$, with

Table $1 \mathrm{Ar}-\mathrm{Ar}$ and $\mathrm{K}-\mathrm{Ar}$ age determinations of potassic rocks from eastern Tibet

Ar-Ar age determinations*

\begin{tabular}{|c|c|c|c|c|c|c|c|c|}
\hline Sample & Location & Rock type & Phase dated & $\begin{array}{l}\text { Plateau } \\
\text { age } \\
(\mathrm{Myr} \pm \sigma)\end{array}$ & $\begin{array}{c}\text { Isochron } \\
\text { age } \\
(\mathrm{Myr} \pm \sigma)\end{array}$ & $\begin{array}{c}\left({ }^{40} \mathrm{Ar} /{ }^{36} \mathrm{Ar}\right)_{0} \\
( \pm \sigma)\end{array}$ & MSWD & $N$ \\
\hline Y86-71 & $\mathrm{G}-1$ & $\mathrm{SH}$ & WR & $36.6 \pm 0.3$ & $30.5 \pm 1.5$ & $261.4 \pm 13.0$ & 3.4 & 11 \\
\hline Y86-172 & G-1 & TA & WR & $33.4 \pm 0.3$ & $32.9 \pm 0.3$ & $288.2 \pm 2.8$ & 0.7 & 6 \\
\hline V111 & G-1 & $\mathrm{TR}$ & WR & $35.3 \pm 0.2$ & $35.3 \pm 0.2$ & $304.8 \pm 13.5$ & 1.4 & 11 \\
\hline T770 & G-1 & $\mathrm{TA}$ & WR & $35.1 \pm 0.2$ & $35.0 \pm 0.2$ & $335.1 \pm 9.4$ & 1.5 & 11 \\
\hline P201 & G-1 & $\mathrm{SH}$ & WR & $35.3 \pm 0.2$ & $35.5 \pm 0.4$ & $269.5 \pm 13.1$ & 4.4 & 4 \\
\hline P9481 & G-1 & $\mathrm{SH}$ & WR & $29.1 \pm 0.9$ & $30.0 \pm 1.1$ & $315.2 \pm 18.6$ & 6.8 & 13 \\
\hline YRR35A & G-2 & TA & WR & $36.9 \pm 0.2$ & $36.7 \pm 0.3$ & $319.0 \pm 27.2$ & 1.5 & 8 \\
\hline YRR35B & G-2 & TA & WR & $34.7 \pm 0.2$ & $34.7 \pm 0.2$ & $278.4 \pm 12.3$ & 1.3 & 9 \\
\hline 96YN131 & G-1 & TA & Biot. & $32.8 \pm 0.2$ & $32.8 \pm 0.2$ & $298.0 \pm 16.9$ & 0.5 & 7 \\
\hline 96YN132 & G-1 & TA & Biot. & $33.9 \pm 0.3$ & $33.9 \pm 0.3$ & $288.4 \pm 2.9$ & 2.1 & 11 \\
\hline 96YN135 & G-1 & TA & Biot. & $33.1 \pm 0.2$ & $33.1 \pm 0.2$ & $332.9 \pm 18.8$ & 0.9 & 8 \\
\hline 96YN137 & G-1 & TA & Biot. & $34.1 \pm 0.3$ & $34.1 \pm 0.3$ & $297.4 \pm 6.1$ & 1.7 & 11 \\
\hline 96YN140 & G-1 & $\mathrm{SH}$ & Phlog. & $32.9 \pm 0.2$ & $32.9 \pm 0.2$ & $294.7 \pm 5.9$ & 1.3 & 7 \\
\hline 96YN148 & G-1 & $\mathrm{SH}$ & Phlog. & $33.2 \pm 0.2$ & $33.2 \pm 0.2$ & $309.9 \pm 26.1$ & 0.7 & 8 \\
\hline
\end{tabular}

K-Ar age determinations $\dagger$

Sample Location Rock type Phase dated

\begin{tabular}{|c|c|}
\hline $\begin{array}{l}\text { Y86-155 } \\
83-703 \\
\text { Y86-110 } \\
\text { Y86-130 } \\
\text { Y86-71 } \\
\text { Y86-99 } \\
\text { Y86-181 } \\
\text { Y86-172 } \\
\text { Y86-185 } \\
81-974 \\
81-751\end{array}$ & $\begin{array}{l}\text { G-1 } \\
\text { G-1 } \\
\text { G-1 } \\
\text { G-1 } \\
\text { G-1 } \\
\text { G-1 } \\
\text { G-1 } \\
\text { G-1 } \\
\text { G-1 } \\
\text { G-1 } \\
\text { G-1 }\end{array}$ \\
\hline $\begin{array}{l}81-862 \\
81-599 \\
81-911\end{array}$ & $\begin{array}{l}\text { G-2 } \\
\text { G-2 } \\
\text { G-2 }\end{array}$ \\
\hline
\end{tabular}

83-55

83-105

83-99

83-931

82-106

$\mathrm{N}-1$

$\mathrm{N}-2$

$\mathrm{N}-3$

$\mathrm{ZH}-1$

$\mathrm{ZA}-1$

85-142

EDG-1

\begin{tabular}{|c|c|}
\hline $\mathrm{SH}$ & WR \\
\hline GS & Biot. \\
\hline TR & WR \\
\hline $\mathrm{SH}$ & WR \\
\hline $\mathrm{SH}$ & Phlog. \\
\hline $\mathrm{SH}$ & Phlog. \\
\hline $\mathrm{SH}$ & Phlog. \\
\hline TR & WR \\
\hline $\mathrm{SH}$ & WR \\
\hline TR & Biot. \\
\hline SY & Biot. \\
\hline TR & Biot. \\
\hline SY & Biot. \\
\hline SY & Biot. \\
\hline
\end{tabular}

$\underset{(w+\%)}{K}$ $\left(10^{6} \mathrm{~mol} \mathrm{~g}^{-1}\right)$

4.57
7.93

7.93
4.57

1.93

7.19
7.51

7.51
7.39

7.39
2.84
5.85

5.85

7.20

7.40

$7.30 \quad 0.46999$

$\begin{array}{ll}7.28 & 0.46999 \\ 7.25 & 0.46254\end{array}$

$\begin{array}{ll}7.28 & 0.43509\end{array}$

0.24349
0.48761

0.29922

0.11497

0.45648

0.46546

0.16122

0.33783

0.42285

$7.63 \quad 0.49852$

0.49852

0.43984

0.49200

0.52970

7.56
7.64

7.64
7.39
$\ldots . .1 \ldots \ldots . .$.

0.53109

6.79

6.79
3.72
7.49
4.57

7.49
4.57

8.82

7.21
2.80

0.41291

0.23023

0.52528

0.27753

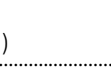
$(\mathrm{Myr} \pm \sigma)$

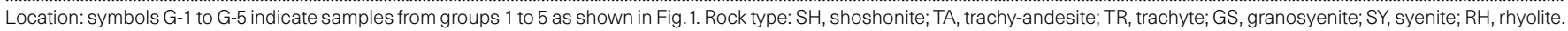
Phase dated: WR, whole rock; Biot., biotite; phlog., phlogopite; K-feld., potash feldspar.

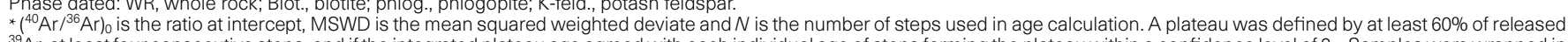

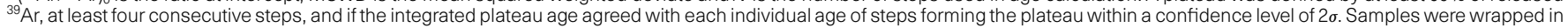

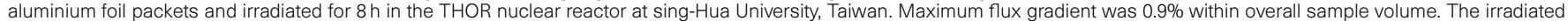
samples were step-heated using a Lindberg resistance furnace and analysed by a Varian-MAT GD150 mass spectrometer at National Taiwan University. The monitor standard was the L P-6

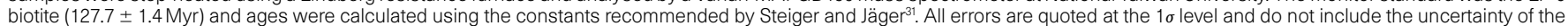
monitor age. Experimental details as given in refs 32,33

$\dagger \mathrm{K}$-Ar age data were determined by conventional potassium-argon dating procedures at Institute of Geochemistry, Chinese Academy of Sciences. Uncertainties given as $1 \sigma$ level. 
accompanying well data, in the Bengal basin has revealed that the Ganges-Brahmaputra delta started to grow rapidly $\sim 40 \mathrm{Myr}$ ago with an increase of sediment flux and development of significant prograding clastic depositional sequences. These sedimentation records are consistent with our view (based on the magmatism) that suggests an earlier rapid rise of eastern Tibet, from where thick piles of the lower sedimentary sequences in the Ganges-Brahmaputra delta and the Bengal fan could have been derived. A similar diachronous uplift history has been also proposed in the northern margin of the Tibetan plateau ${ }^{27}$. On the basis of radiometric dating results of granites and gneisses, Arnaud et al. ${ }^{27}$ have argued that the basement unroofing and uplift in the eastern Kunlun Range occurred since $\sim 35 \mathrm{Myr}$ ago, and apparently preceded those in the western part of the Range.

Consequently, we suggest that the Tibetan plateau has undergone two main stages of rapid uplift caused by diachronous removal of thickened Asian lithosphere after the Indian indentation. Whereas the younger, and better-known, uplift began $\sim 20 \mathrm{Myr}$ ago in the western part of Tibet, the earlier event took place in the east, since $\sim 40 \mathrm{Myr}$ ago. Our observation can be reconciled with tectonic forcing models for the Cenozoic isotope evolution in the ocean ${ }^{9}$ and global climate change ${ }^{10}$; these models put forward the effects of the rise and subsequent erosion and weathering of the Tibetan-Himalayan region. More specifically, it provides the first (to our knowledge) convincing time constraint that accommodates not only the rapid and steady increase in the seawater strontium isotope ratios beginning $40 \mathrm{Myr}$ ago $^{9}$ but also the onset of global cooling from the early Eocene ${ }^{10}$.

We further propose that the late Palaeogene tectonic processes in eastern Tibet played an important role in initiating the Ailao ShanRed River shear zone, thus causing the continental extrusion ${ }^{28}$ which eventually offset the Indochina block from the South China block for about $600 \mathrm{~km}$ (ref. 16). This may be due to the occurrence of a mechanically weakened lithosphere domain in the eastern Tibetan region as a result of the earlier lithospheric removal associated with extension and upwelling of hotter asthenosphere. The continental extrusion took place from about 27 to $17 \mathrm{Myr}$ ago ${ }^{16,29}$, nearly coincident with the motion of the Gangdese thrusting system in the southernmost Tibet ${ }^{3,30}$. Such a synchroneity relates to the long-standing debate on the relative importance of crustal thickening and lateral extrusion after the India-Asia collision. Future detailed investigations of this inaccessible mountainous region are needed for a more comprehensive understanding of the geological evolution of Tibet. In the absence of such data, any tectonic approaches using the one-stage uplift model for the entire Tibetan plateau may have to face the problem of oversimplification.

Received 22 April 1997; accepted 10 June 1998.

1. Platt, J. P. \& England, P. C. Convective removal of lithosphere beneath mountain belts: Thermal and mechanical consequences. Am. J. Sci. 294, 307-336 (1994).

2. Coleman, M. \& Hodges, K. Evidence for Tibetan plateau uplift before $14 \mathrm{Myr}$ ago from a new minimum age for east-west extension. Nature 374, 49-52 (1995).

3. Harrison, T. M., Copeland, P., Kidd, W. S. F. \& Yin, A. Raising Tibet. Science 255, 1663-1670 (1992).

4. Molnar, P., England, P. \& Martinod, J. Mantle dynamics, the uplift of the Tibetan pleateau, and the Indian monsoon. Rev. Geophys. 31, 357-396 (1993).

. Turner, S. et al. Timing of Tibetan uplift constrained by analysis of volcanic rocks. Nature 364, 50-54 (1993).

6. Turner, S. et al. Post-collisional, shoshonitic volcanism on the Tibetan plateau: implications for convective thinning of the lithosphere and the source of ocean island basalts. J. Petrol. 37, 45-71 (1996).

. Lindsay, J. F., Holliday, D. W. \& Hulbert, A. G. Sequence stratigraphy and the evolution of the GangesBrahmaputra Delta complex. Am. Assoc. Petrol. Geol. Bull. 75, 1233-1254 (1991).

8. Curray, J. R. Sediment volume and mass beneath the Bay of Bengal. Earth Planet. Sci. Lett. 125, $371-$ 383 (1994).

9. Richter, F. R., Rowley, D. B. \& DePaolo, D. J. Sr isotope evolution of seawater: The role of tectonics. Earth Planet. Sci. Lett. 109, 11-23 (1992).

10. Raymo, M. E. \& Ruddiman, W. F. Tectonic forcing of late Cenozoic climate. Nature 359, 117-122 (1992)

11. Copeland, P., Harrison, T. M., Pan, Y., Kidd, W. S. F. \& Roden, M. Thermal evolution of the Gangdese batholith, southern Tibet: A history of episodic unroofing. Tectonics 14, 223-236 (1995).

12. Zhang, Y. Q., Xie, Y. W. \& Tu, G. Z. Preliminary studies of the alkali-rich intrusive rocks in the Ailaoshan-Jinshajiang belt and their bearing on rift tectonics. Acta Petrol. Sinica 3, 17-26 (1987).

13. Pearce, J. A. \& Mei, H. Volcanic rocks of the 1985 Geotraverse: Lhasa to Golmud. Phil. Trans. R. Soc Lond. A 327, 169-201 (1988).
14. Zhu, B. Q., Zhang, Y. Q. \& Xie, Y. W. Isotope characteristics of Cenozoic potassic volcanic rocks from Haidong, Yunnan, and their implications for subcontinental mantle evolution in southwestern China. Geochimica 21, 201-212 (1992).

15. Bureau of Geology and Mineral Resources of Xizang Region Regional Geology of Xizang (Tibet) (Geol. Publ. House, Beiijing, 1993).

16. Chung, S. L. et al. Intraplate extension prior to continental extrusion along the Ailao Shan-Red River shear zone. Geology 25, 311-314 (1997)

17. Ratschbacher, L., Frisch, W., Chen, C. \& Pan, G. in The Tectonic Evolution of Asia (eds Yin, A. \& Harrison, T. M.) 227-249 (Cambridge Univ. Press, 1995).

18. Holt, W. E, Ni, J. F, Wallace, T. C. \& Haines, A. J. The active tectonics of the eastern Himalayan syntaxis and surrounding regions. J. Geophys. Res. 96, 14595-14632 (1991).

19. Beck, R. A. et al. Stratigraphic evidence for an early collision between northwest India and Asia. Nature 373, 55-57 (1995).

20. Lee, T. Y. \& Lawver, L. A. Cenozoic plate reconstruction of Southeast Asia. Tectonophysics 251, 85-138 (1995).

21. Bureau of Geology and Mineral Resources of Yunnan Province Regional Geology of Yunnan Province (Geol. Publ. House, Beijing, 1990).

22. Leloup, P. H. et al. The Ailao Shan-Red River shear zone (Yunnan, China), Tertiary transform boundary of Indochina. Tectonophysics 251, 3-84 (1995).

23. Kan, R. J., Hu, H. X., Zeng, Rr. S., Mooney, W. D. \& McEvilly, T. V. Crustal structure of Yunnan Province, People's Republic of China, from seismic refraction profiles. Science 234, 433-437 (1986). 24. Houseman, G. From mountains to basin. Nature 379, 771-772 (1996).

25. Copeland, P. \& Harrison, T. M. Episodic rapid uplift in the Himalaya revealed by ${ }^{40} \mathrm{Ar} /{ }^{39} \mathrm{Ar}$ analysis of detrital K-feldspar and muscovite. Geology 18, 354-357 (1990).

26. Johnson, M. R. W. Volume balance of erosional loss and sediment deposition related to Himalayan uplifts. J. Geol. Soc. Lond. 151, 217-220 (1994).

27. Arnaud, N. O. et al. Ages of magmatism and tectonism of north eastern Kunlun, China. 30th Int. Geol. Congr. (Beijing) Abstr. 1, 192 (1996).

28. Trapponnier, P., Peltzer, G., Armijo, R., Le Dain, A. Y. \& Cobbold, P. Propagating extrusion tectonics in Asia: New insights from simple experiments with plasticine. Geology 10, 611-616 (1982).

29. Wang, P. L. et al. Movement of the Aialo Shan-Red River shear zone: A Vietnamese perspective from thermochronological evidence. Eos 78, F649 (1997).

30. Yin, A. et al. Tertiary structural evolution of the Gangdese thrust system in southeastern Tibet. J. Geophys. Res. 99, 18175-18201 (1994).

31. Steiger, R. H. \& Jäger, E. Submission on geochronology: Convention on the use of decay constants in geo- and cosmochronology. Earth Planet. Sci. Lett. 36, 359-362 (1977).

32. Lo, C. H. \& Lee, C. Y. ${ }^{40} \mathrm{Ar} /{ }^{39} \mathrm{Ar}$ method of K-Ar age determination of geological samles using sing-Hua Open-pool (HOR) Reactor. J. Geol. Soc. China 37, 143-164 (1994).

33. Lo, C. H., Onstot, T., Chen, C. H. \& Lee, T. Ar/Ar dating of andesitic volcanism in the Luzon arc near Taiwan. Chem. Geol. 114, 157-178 (1994).

34. Le Fort, P. Granite in the tectonic evolution of the Himalaya, Karakorum, and southern Tibet. Phil. Trans. R. Soc. Lond. A 327, 281-299 (1988).

35. Le Maitre, R. W. (ed.) A Classification of Igneous Rocks and Glossary of Terms (Blackwell Sci. Publ, Oxford, 1989).

36. Sun, S.-s. \& McDonough, W. F. in Magmatism in the Ocean Basins (eds Saunders, A. D. \& Norry, M. J.) 313-345 (Spec. Publ. 42, Geol. Soc., London, 1989).

Supplementary information is available on Nature's World Wide Web side (http://www.nature.com) or as paper copy from the London editorial office of Nature.

Acknowledgements. We thank A. Crawford, S.-s. Sun and F. Yang for suggestions on the earlier drafts, and N. Rogers and P. England for reviews which significantly improved this Letter. This study was supported by the National Science Council, Taiwan and the National Science Foundation, China.

Correspondence and requests for materials should be addressed to S.L.C. (e-mail: sunlin@ccms.ntu.edu. tw).

\section{Evolutionary transition from stretch to hearing organs in ancient grasshoppers}

\author{
Moira J. van Staaden $*$ \& Heiner Römer \\ Institute for Zoology, University of Graz, A-8010 Graz, Austria
}

Ears of modern insects occur on a wide variety of body parts and are thought to have evolved from ubiquitous stretch or vibration receptors ${ }^{1-4}$. This relationship, based on comparative anatomy and similarities in the embryological development of ears in divergent $\operatorname{taxa}^{5-7}$, has led to the widespread assumption of homology of these structures in insects, although this has not been tested rigorously. Here we report on the hearing organs of a relatively ancient $^{8}$, atympanate bladder grasshopper ${ }^{9-11}$ (Bullacris membracioides), which is capable of signalling acoustically over $\sim 2 \mathrm{~km}^{12}$. We show that, within single individuals of this species, serially repeated abdominal ears show functional continuity from simple to more complex forms. All 12 morphologically differentiated

${ }^{\star}$ Present address: Department of Biological Sciences, Bowling Green State University, Bowling Green, Ohio 43403, USA 